\title{
Transcranial Magnetic Stimulation (TMS) Applications in Alzheimer's Disease: A Systematic Review
}

\section{Alzheimer Hastalığında Traskraniyal Manyetik Stimülasyon (TMS) Uygulamaları Üzerine Sistematik Bir Derleme}

\author{
(D) Halil Aziz VELIOĞLU1', iD Muhammed Yunus BEKTAY²
}

${ }^{1}$ Istanbul Medipol University, Health Sciences and Technology Research Institute (SABITA), Regenerative and Restorative Medicine Research

Center (REMER), functional Imaging and Cognitive-Affective Neuroscience Lab (fINCAN), Istanbul, Turkey

2Bezmialem Vakıf University Faculty of Pharmacy, Department of Clinical Pharmacy, Istanbul, Turkey

\begin{abstract}
Alzheimer's disease $(\mathrm{AD})$, is characterized by its progressive feature and loss of cognitive functions, is common among dementia types. There is no curative treatment of the disease today. In recent years, transcranial magnetic stimulation (TMS) techniques together with drug therapy have been explored by experts considering that they will produce beneficial results. Repetetive TMS (rTMS) can modulate cortical excitability and prevent long-term neuroplastic changes. The aim of this study is an updated and comprehensive systematic review of studies using TMS/rTMS in AD patients. Our study was designed as a systematic review prepared according to the PRISMA guideline. In this study, English and Turkish AD-TMS articles that entered the literature published between 2002 and 2017 were included. Randomized and non-randomized controlled clinical studies on humans evaluating the effectiveness of rTMS applications at different concentrations, durations and different regions in $\mathrm{AD}$ have been reviewed. The databases we used were Pubmed $^{\circ}$, MEDLINE ${ }^{\bullet}$, Webofscience ${ }^{\circ}$, EMBASE ${ }^{\bullet}$, Türkiye Atif Dizini. Keywords were "TMS, rTMS, Alzheimers Disease" used in our search, 116 artticles complied with the determined protocol were identified and 14 were included in our study. The studies presented in this review, show the therapeutic potential of rTMS in
\end{abstract}

\section{ÖZ}

İlerleyici özelliği ve bilişsel fonksiyonların kaybı ile karakterize olan Alzheimer hastalığı (AH), demans türleri arasında sık karşılaşılanıdır. Hastalığııın günümüzde küratif bir tedavisinin yoktur. Son yıllarda ilaç tedavisinin yanında transkraniyal manyetik stimülasyon (TMS) tekniklerinin, uzmanlar tarafindan faydalı sonuçlar oluşturacağı düşünülerek araştırılmaktadır. Tekrarlı TMS (rTMS) kortikal uyarılabilirliği modüle edebilir ve uzun süreli nöroplastik değişiklikleri önleyebilir. Bu çalışmanın amacı, AH hastalarında TMS/rTMS kullanan çalışmaların güncellenmiş ve kapsamlı bir sistematik derlemesini oluşturmaktadır. Çalışmamız PRISMA kılavuzuna göre hazırlanmıs bir sistematik derleme olarak tasarlanmıştır. Araşırımamızda 2002-2017 tarihleri arasında literatüre girmiş İngilizce ve Türkçe AH-TMS araşırımaları taranmıştır. Farklı yoğunluklarda, sürelerde ve farklı bölgelere yapılan rTMS uygulamalarının AH'de etkinliğini değerlendiren randomize ve non-randomize kontrollü klinik çalışmalar gözden geçirilmiştir. Taramadan kullandığımı veri tabanları Pubmed ${ }^{\circ}$, Medline ${ }^{\circ}$, Webofscience ${ }^{\circ}$ EMBASE॰ Türkiye Atıf Dizini`'dir. Taramamızda anahtar kelime olarak "TMS, rTMS, AH" kullanılmıştır. Hayvanlar ve deney modellerinde yapılan çalışmalar taramamız kapsamında dışlanmıştır. Belirlenen protokole uygunluğu bulunan 116 makale belirlenmiş ve 14 'ü çalışmamıza dahil edilmiştir. Bu derlemede sunulan çalışmalar, AH'den etkilenen bilişsel alanlardan bazılarına fayda sağlayan, demansı iyileştiren ve işlevsellikte daha iyi performansa neden olan etkileri gözlemleyerek $\mathrm{AD}$ hastalarında

Address for Correspondence: Muhammed Yunus BEKTAY, Bezmialem Vakıf University Faculty of Pharmacy, Department of Clinical Pharmacy, İstanbul, Turkey

E-mail: yunusbektay@gmail.com ORCID ID: orcid.org/0000-0003-2032-9957 
AD patients. Benefits of rTMS were to communicate with patients and especially caregivers in their daily activities, thereby improving their QoL. The possibility of using TMS to increase neuroplasticity is promising not only to improve our understanding of brain plasticity mechanisms, but also to design new neurorehabilitation strategies.

Keywords: Alzheimer's disease, dementia, rTMS
rTMS'nin terapötik potansiyelini göstermektedir. rTMS'nin spesifik faydaları, günlük aktivitelerinde hastalar için, özellikle de bakıcı ve hastalıkla ilişkili davranışla iletişim kurma yetenekleri, böylece yaşam kalitelerini iyileştirme ve hatta erken koşullar için tıbbi hizmetlerin kullanımını sınırlandırma ve kurumsallaşma. Beyin stimülasyonunu nöroplastisiteyi artırmak için bir araç olarak kullanma olasılığı, sadece beyin plastisite mekanizmaları hakkındaki anlayışımızı geliştirmek için değil, aynı zamanda yeni nörorehabilitasyon stratejileri tasarlamak için de umut vericidir.

Anahtar Sözcükler: Alzheimer hastalığı, demans, rTMS

\section{Introduction}

Alzheimer's disease (AD) is the most common type of dementia, characterized by progressive loss of cognitive functions. The disease is often accompanied by loss of memory functions, decreased orientation ability, and motor dysfunctions. In addition to the symptoms such as aphasia, agnosia, and apraxia the main symptom in $\mathrm{AD}$ is memory dysfunction. $\mathrm{AD}$ is associated with synaptic dysfunction at the cellular level, with amyloid beta and tau protein accumulation (1). Loss of cognitive and motor function as a result of the progressive nature of the disease ultimately leads to death.

Today, the absence of a curative alternative in the treatment of $\mathrm{AD}$ obliges healthcare professionals to find treatments aimed at slowing the course of the disease and reducing cognitive damage. These treatment approaches are mostly carried out through pharmacological agents. However, pharmacological agents cannot produce an effective solution to the course of $\mathrm{AD}$ and they bring other problems with them due to their high side-effect profile. Therefore, scientists have turned to research different methods other than pharmacological agents for the treatment of this disease.

Transcranial Magnetic Stimulation (TMS), which has been used in the treatment of depression for a long time with successful results, is also used as a promising alternative treatment in neurodegenerative diseases (2). TMS is a non-invasive method that aims to stimulate or inhibit certain parts of the brain as a result of applying the magnetic field created outside the body on the scalp. TMS treatment seems to be advantageous in some respects compared to the pharmacological approach. Easy to apply, low side-effect profile as well as positive behavioral and cognitive results suggest that TMS can be preferred over pharmacological agents.

The dorsolateral prefrontal cortex (DLPFC) is mostly preferred as the target area to stimulate in the treatment of AD with TMS (3). In general, although this treatment protocol has led to improvements in executive functions, attention and behavioral functions in individuals with $\mathrm{AD}$, completely satisfactory results could not be obtained in memory functions. Therefore, different protocols are being investigated and studies are continuing to obtain more effective results with TMS treatment.
In addition to the pharmacological alternatives used in AD, repetetive Transcranial Magnetic Stimulation (rTMS) applications with promising results in the treatment will be examined in our study. Randomized and non-randomized controlled clinical studies evaluating the effectiveness of TMS applications at different intensities and in different regions in $\mathrm{AD}$ were reviewed in this study.

\section{Methods}

This study, designed as a systematic review, English and Turkish AD-TMS studies between 2002-2017 were screened. The evaluation of the studies were made according to application area of TMS [Broca, Wernicke, right-left DLPFC, right-left parietal somato-sensory association cortex (PSAC)], frequency (1-20 $\mathrm{Hz}$ ), online-offline applications, and duration (from 1 session to 6 weeks). During our literature search, randomized and non-randomized controlled clinical studies and human studies were searched with the keywords "TMS, rTMS and Alzheimers Disease” in Pubmed $^{\circledR}$, Medline $^{\circledR}$, Webofscience $^{\circledR}$, EMBASE$^{\circledR}$, and Turkey Citation Index search engines. Animal studies and experimental models were excluded. The last screening was made on 31 December 2017.

Analysis method and inclusion criteria were predetermined and documented in Figure 1. Randomized and non-randomized controlled studies evaluating the effectiveness of rTMS applications of different intensities and different regions in $\mathrm{AD}$ were reviewed. The reliability of the reviewed articles was evaluated in terms of evidence levels and some were eliminated after evaluated in terms of insufficiency of control group, randomization, bias, and small sample size. The number of articles included is given in Figure 1.

Data gathered from each included study were as follows; (1) characteristics of study participants (age, presence of AD type dementia, disease severity); (2) the type, dose, duration, and frequency of intervention (duration, intensity, and site of rTMS administration), current treatment versus placebo or another treatment; (3) type of outcome measure (improved cognitive function, improved quality of life, increased daily activities). 

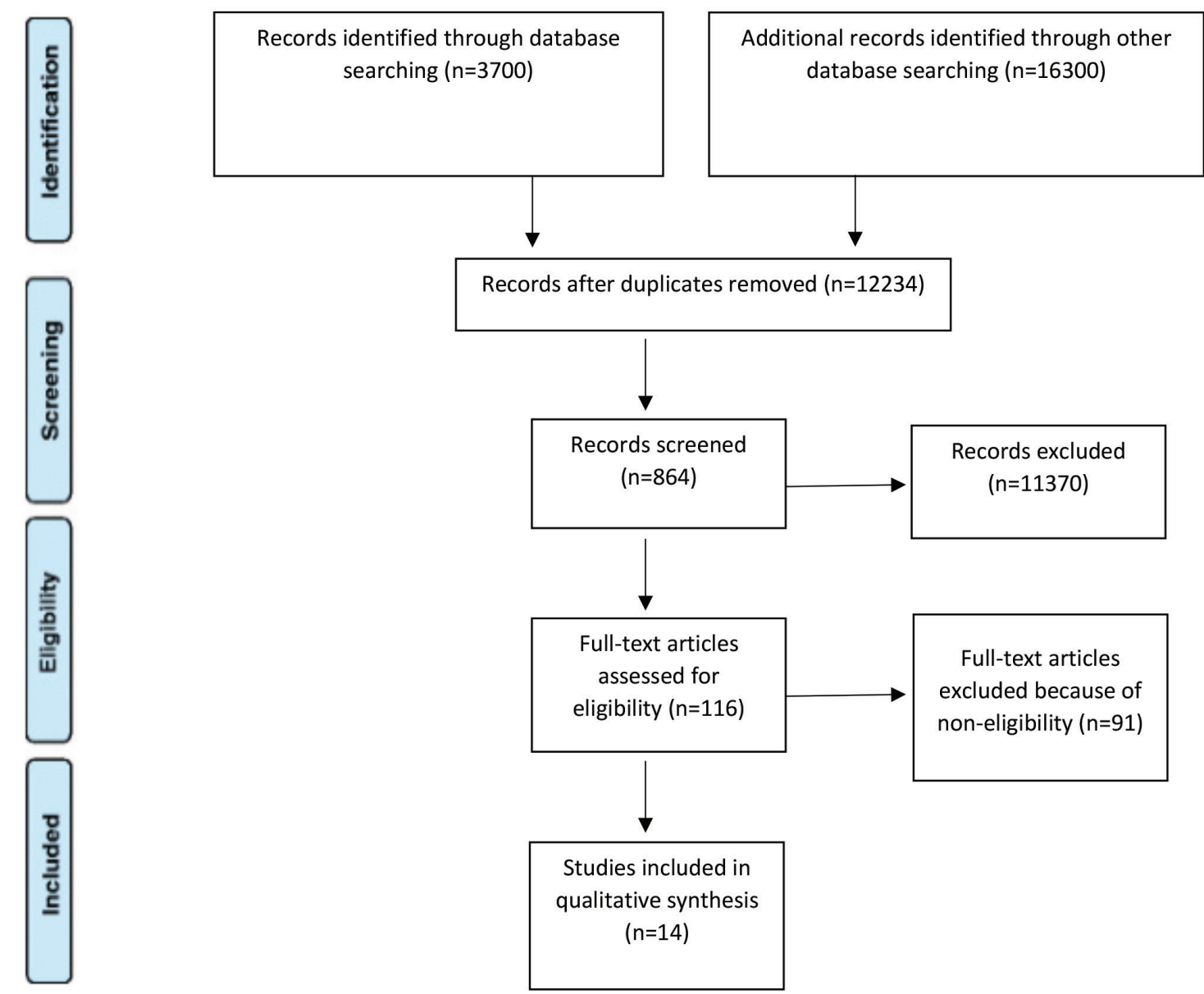

Figure 1. Flow diagram according to PRISMA study protocol (41)

\section{Discussion}

The magnetic field principle, discovered by Faraday in the $19^{\text {th }}$ century, constitutes the basic working system of TMS (4). According to this system, the electric current passing in a wire coil causes magnetic flux in another conductor nearby, which can create an electric field in another conductor in the immediate vicinity. Similarly, a high density and faster than $1 \mathrm{~ms}$ electrical current produced in the TMS device is passed through the coil and a magnetic field of 2.5 tesla is obtained. When this magnetic field is directed perpendicular to the skull, it can create an electrical current in nerve cells (5). The magnetic field created by TMS is not a constant magnetic field, but a magnetic field characterized by intermittant pulses. Thus, it becomes possible to stimulate brain cells with magnetic pulses created one after another. The induced magnetic field, which passes through the skull and reaches the cortical areas, causes depolarization in the cells and creates neurophysiological responses (6).

Considering the density of the scalp, skull and cerebrospinal fluid, the effectiveness of TMS is limited to a distance $2 \mathrm{~cm}$ from the scalp. Because of this limited area of action, it is difficult for TMS stimulation to reach subcortical regions (7). With the developing technology, the area of influence of TMS can extend to deeper regions. However, new systems cause more stimulation of the regions in the cortex during the stimulation of the subcortical regions (8).

TMS has been an important tool in the investigation of various neurological and psychiatric disorders since it was first developed (9). The use of TMS in the treatment of drug-resistant major depression was approved by the American Food and Drug Administration (FDA) in 2008 (10). Following this approval, the FDA's approval of the use of TMS in the treatment of drugresistant migraine caused it to be used in many clinics around the world (11).

As a specialized TMS protocol, a long-term modulating effect on brain activity can be achieved with rTMS. rTMS makes it possible for all of the stimulating magnetic pulses to be given together in order to create an effect in the cortical area in one stimulation period (12). Due to its long effect profile, rTMS is 
considered as a promising treatment option in diseases such as major depression, chronic pain and epilepsy (13).

Drugs developed in $\mathrm{AD}$ type dementia have been used for more than 20 years, but researchers have turned to new treatment approaches because these drugs do not have the desired level of efficacy and cannot slow the prognosis of the disease sufficiently (14). In this respect, rTMS has an important place among the new treatment approaches considered in the treatment of $\mathrm{AD}$. Being noninvasive, painless and reliable are the prominent advantages of rTMS (15). Nevertheless, a curative treatment is not obtained with TMS and TMS does not restore atrophied tissues. However, it is thought that the course of the disease may improve as a result of slowing the progression and increasing the synaptic connectivity between neurons with this treatment (16).

As a result of magnetic stimulation treatment, cognitive functions such as mood, executive functions, learning, memory and attention were increased. In randomized controlled studies, it has been determined that rTMS applied to the right DLPFC may cause an increase in episodic memory functions (17-19). Although the DLPFC is frequently targeted in $\mathrm{AD}$, there are studies in the literature in which TMS is applied to Broca, Wernicke, PSAC, inferior temporal gyrus, inferior frontal gyrus (IFG), and superior temporal gyrus (STG) areas (20). On the other hand, rTMS applications to different regions have been shown to affect different cognitive and behavioral functions. It has been shown that magnetic stimulation to the motor cortex for improving motor functions and TMS applications to the prefrontal cortex found beneficial for mood, depression, and cognitive functions. It has also been reported to improve cognitive functions in patients with mild to moderate $\mathrm{AD}(21)$. In addition to frequency differences, the regions where TMS application is made also vary. Different application methods (application area, frequency, duration of application, etc.) have been developed for to modulate behavioral and motor symptoms such as mood, cognition, anxiety, memory, executive functions (22). High frequency $(>5 \mathrm{~Hz})$ is preferred in TMS protocols when stimulation is aimed. On the other hand low frequency $(1 \mathrm{~Hz})$ is preferred in protocols for inhibition $(23,24)$. Also in some protocols, TMS and pharmacological treatment can be used together. Another method to increase the effectiveness is online-TMS protocols. In this protocols cognitive tasks related to the function of the application area apply to patients during TMS application.

The Alzheimer-TMS studies published in the last 15 years and the results of the changes in patients are listed in Table 1.

In 2006 Cotelli et al. (25) performed a single session of $20 \mathrm{~Hz}$ TMS on the right and left DLPFC of 15 patients. In the study, the Object-Action Picture-Naming test results of the TMS applied group and the sham control group were compared. They reported that the action naming capacity of the TMS group was increased compared to the sham control (25).

Again, Cotelli et al. (3) applied $20 \mathrm{~Hz}$ single session TMS to the right and left DLPFC in their randomized controlled study in 2008. In the study, which included 12 patients with mild AD and 12 patients with moderate-severe $\mathrm{AD}$, patients with mild $\mathrm{AD}$ type dementia showed an increase in object and action naming capacity compared to the sham group. On the other hand, both action and object naming skills were improved in patients with moderate-to-severe $\mathrm{AD}(3)$.

In another study conducted by Cotelli et al. (26) in 2011, rTMS was applied in 10 patients with AD only to the left DLPFC and an increase in the cognitive functions of the patients was reported. They applied $20 \mathrm{~Hz}$ rTMS for 4 weeks to the first of the two patient groups, and placebo TMS for 2 weeks and rTMS for 2 weeks to the second group. Mini Mental State Exemination (MMSE), Activities of Daily Living (ADL), The Lawton Instrumental ADL (IADL), Picture Naming Test, and Battery for Analysis of Aphasic Deficits (SC-BADA) were used as evaluation criteria. In the obtained results, a significant difference was observed only in one of the subtests of SC-BADA, and it was observed that TMS stimulation caused an increase in the perception of the heard sentences (26).

Bentwich et al. (27) investigated the effects of long-term TMS treatment protocol in 7 patients with AD. Bentwich et al. (27) targeted Broca, Wernicke, the right-left DLPFC and rightleft PSAC as the application sites and applied $10 \mathrm{~Hz}$ TMS to the patients 5 days a week for 6 weeks and 2 days a week for the following 3 months. In this online-TMS protocol study, The Alzheimer's Disease Assessment Scale-Cognitive Subscale (ADAS-Cog) scores were evaluated together with cognitive assessments, and statistically significant improvements were observed (27).

Ahmed et al. (24) divided 45 patients with AD (13 severe dementia and 32 mild dementia) into $20 \mathrm{~Hz}, 1 \mathrm{~Hz}$ and sham groups. rTMS was applied to the right and left DLPFC for 5 days, and the cognitive assessment was repeated at the end of 1 and 3 months after TMS application. Compared to the sham control, significant improvements were noted in the IADL score in the $1 \mathrm{~Hz}$ treatment group. On the other hand, an increase was observed in all MMSE, Geriatric Depression Scale (GDS) and IADL scores in the $20 \mathrm{~Hz}$ group (24).

Haffen et al. (28) shared the results of 10 sessions of $10 \mathrm{~Hz}$ TMS application on 1 patient in 2012. In the study, the patient was subjected to cognitive evaluation 3 times, 4 months before the treatment and 1 month and 5 months after the treatment. In the second and third cognitive evaluations, significant improvements were noted in episodic memory and rapid processing skills compared to baseline. However, as a result of the comparison of the third evaluation with the second, the patient's cognitive functions returned back, in other words, worsened. As a result of their study, Haffen et al. (28) concluded that the effect of TMS application decreased over time.

In an online TMS study, Rabey et al. (29) combined stimulation protocol with cognitive assessments, and applied 54 sessions of $10 \mathrm{~Hz}$ TMS to the right-left DLPFC, right-left PSAC, Broca and Wernicke areas 5 days a week for 6 weeks and 2 days a week for the following 3 months in 15 patients with $\mathrm{AD}$. When the 
Table 1. Literature on rTMS applications in Alzheimer's disease, 2002-2017

\begin{tabular}{|c|c|c|c|c|}
\hline Number of Patients & $\begin{array}{l}\text { Localization } \\
\text { of application }\end{array}$ & $\begin{array}{l}\text { Application } \\
\text { duration and } \mathrm{Hz}\end{array}$ & Improved function & Reference \\
\hline $15 \mathrm{AD}$ & Right-left DLPFC & One session $20 \mathrm{~Hz}$ & $\begin{array}{l}\text { Improvement in Object Naming test } \\
\text { compared to Sham }\end{array}$ & Cotelli et al. 2006 \\
\hline $\begin{array}{l}12 \text { mild } A D(1) \\
12 \text { moderate } A D(2)\end{array}$ & $\begin{array}{l}\text { Right-left DLPFC } \\
\text { Right-left DLPFC }\end{array}$ & One session $20 \mathrm{~Hz}$ & $\begin{array}{l}\text { (1) Improvement in Action Naming test } \\
\text { compared to Sham } \\
\text { (2) Improvement in Action-Object } \\
\text { Naming test } \\
\text { compared to Sham }\end{array}$ & Cotelli et al. 2008 \\
\hline $\begin{array}{l}5 \mathrm{AD}(1) \\
5 \mathrm{AD}(2)\end{array}$ & $\begin{array}{l}\text { Left DLPFC } \\
\text { Left DLPFC }\end{array}$ & $\begin{array}{l}4 \text { weeks } 20 \mathrm{~Hz} \\
2 \text { weeks } 20 \mathrm{hz}+2 \text { weeks } \\
\text { Placebo }\end{array}$ & $\begin{array}{l}(1,2) \text { Improved perception of } \\
\text { heard sentences } \\
\text { MRI used for localization determination } \\
\text { for TMS application }\end{array}$ & Cotelli et al. 2011 \\
\hline $7 \mathrm{AD}$ & $\begin{array}{l}\text { Broca, Wernicke, right-left } \\
\text { DLPFC, right-left PSAC }\end{array}$ & $\begin{array}{l}6 \text { weeks } 10 \mathrm{~Hz}+3 \text { months, } 2 \\
\text { days a week } 10 \mathrm{~Hz}\end{array}$ & ADCS-ADL & $\begin{array}{l}\text { Bentwich et al. } \\
2011\end{array}$ \\
\hline $\begin{array}{l}15 \mathrm{AD}(1) \\
15 \mathrm{AD}(2) \\
15 \mathrm{AD}(3)\end{array}$ & $\begin{array}{l}\text { Right-left DLPFC } \\
\text { Right-left DLPFC } \\
\text { Sham }\end{array}$ & $\begin{array}{l}5 \text { days } 20 \mathrm{~Hz} \\
5 \text { days } 1 \mathrm{~Hz} \\
\text { Sham }\end{array}$ & $\begin{array}{l}\text { (1) MMSE, GDS } \\
\text { (2) IADL }\end{array}$ & $\begin{array}{l}\text { Ahmed et al. } \\
2012\end{array}$ \\
\hline $1 \mathrm{AD}$ & Left DLPFC & 2 weeks $10 \mathrm{~Hz}$ & $\begin{array}{l}\text { Assessment } 4 \text { months before, } 1 \text { and } 5 \\
\text { months after TMS, Increase in episodic } \\
\text { memory and rapid processing, decrease } \\
\text { in the third assessment compared to the } \\
\text { second }\end{array}$ & $\begin{array}{l}\text { Haffen et al. } \\
2012\end{array}$ \\
\hline $15 \mathrm{AD}$ & $\begin{array}{l}\text { Broca, Wernicke, right-left } \\
\text { DLPFC, right-left PSAC }\end{array}$ & $\begin{array}{l}\text { Online TMS, } 6 \text { weeks } 10 \mathrm{~Hz}+3 \\
\text { months } 2 \text { days a week } 10 \mathrm{~Hz}\end{array}$ & $\begin{array}{l}\text { ADAS-Cog, CGIC } \\
\text { MRI used for localization determination } \\
\text { for TMS application }\end{array}$ & Rabey et al. 2013 \\
\hline 10 mild $A D$ ve $M C l$ & IFG & $\begin{array}{l}10 \mathrm{~Hz} \text { for } 3 \text { days at } 1 \text { day } \\
\text { intervals }\end{array}$ & Attention and Psychomotor speed & $\begin{array}{l}\text { Eliasova et al. } \\
2014\end{array}$ \\
\hline $\begin{array}{l}6 \mathrm{AD}(1) \\
6 \mathrm{AD}(2)\end{array}$ & $\begin{array}{l}\text { Right-left DLPFC } \\
\text { Right-left DLPFC }\end{array}$ & $\begin{array}{l}4 \text { sessions in } 2 \text { weeks, } 10 \mathrm{~Hz} \\
4 \text { sessions in } 2 \text { weeks, } 15 \mathrm{~Hz}\end{array}$ & $\begin{array}{l}(1,2) \text { Verbal fluency, nonverbal fluency } \\
4 \text { weeks after TMS } \\
\text { fMRI study }\end{array}$ & Devi et al. 2014 \\
\hline $\begin{array}{l}4 A D \\
6 A D\end{array}$ & $\begin{array}{l}\text { Right-left DLPFC } \\
\text { Right-left DLPFC }\end{array}$ & $\begin{array}{l}4 \text { weeks sham } \times 4 \text { weeks } \\
\text { treatment with } 20 \mathrm{~Hz} \\
4 \text { weeks treatment with } 20 \mathrm{~Hz} \\
\text { x } 4 \text { weeks sham }\end{array}$ & MoCA, ADAS-Cog & $\begin{array}{l}\text { Rutherford et al. } \\
2015\end{array}$ \\
\hline $\begin{array}{l}26 \mathrm{AD}(1) \\
26 \mathrm{AD}(2)\end{array}$ & $\begin{array}{l}\text { Left DLPFC + Antipsychotic } \\
\text { (1 mg risperidone) } \\
\text { Sham+ Antipsychotic } \\
\text { (1 mg risperidone) }\end{array}$ & 4 weeks $20 \mathrm{~Hz}$ & BEHAVE-AD, ADAS-Cog & Wu et al. 2015 \\
\hline $30 \mathrm{AD}$ & $\begin{array}{l}\text { Broca, Wernicke, right-left } \\
\text { DLPFC, right-left PSAC }\end{array}$ & Online TMS, 6 weeks $10 \mathrm{~Hz}$ & ADAS-Cog, MMSE & Rabey et al. 2016 \\
\hline $\begin{array}{l}18 \mathrm{AD}(1) \\
18 \mathrm{AD}(2)\end{array}$ & $\begin{array}{l}\text { Broca, Wernicke, right-left } \\
\text { DLPFC, right-left PSAC } \\
\text { Sham }\end{array}$ & Online TMS, 6 weeks $10 \mathrm{~Hz}$ & ADAS-Cog, CGIC & Lee et al. 2016 \\
\hline $\begin{array}{l}17 \text { mild + moderate } \\
A D\end{array}$ & $\begin{array}{l}\text { Parietal P3/P4, posterior } \\
\text { temporal T5/T6 }\end{array}$ & 6 weeks $20 \mathrm{~Hz}$ & $\begin{array}{l}\text { Cognitive functions, language and } \\
\text { memory }\end{array}$ & Zhao et al. 2017 \\
\hline
\end{tabular}

AD: Alzheimer's disease, MCI: Mild cognitive impairment, TMS: Transcranial magnetic stimulation, fMRI: Functional magnetic resonance imaging, DLPFC: Dorsolateral prefrontal cortex, PSAC: Parietal somato-sensory association cortex, IFG: Inferior frontal gyrus, ADCS-ADL: Alzheimer's Disease Cooperative Study- Activities of Daily Living, MMSE: Mini-mental state examination, IADL: The lawton instrumental activities of daily living, SC-BADA: The Battery for Analysis of Aphasic Deficits, ADASCog: Alzheimer's disease assessment scale-cognitive subscale, GDS: Geriatric depression scale, CGIC: Clinical global Impression of change, MoCA: Montreal cognitive assessment, BEHAVE-AD: Behavioral pathology in Alzheimer's disease rating scale 
patients included in the study were evaluated cognitively at 6 weeks and 4.5 months later, increases in ADAS-Cog and Clinical Global Impression of Change (CGIC) scores were observed (29).

In the study of Eliasova et al. (30) published in $2014,10 \mathrm{~Hz}$ rTMS was applied to the IFG of 10 individuals with mild cognitive impairment (MCI) and mild AD, 3 times within 6 days, with an interval of one day. Improvements in attention and psychomotor speed were observed in patients whose results were evaluated with the trail making test (30).

Devi et al. (19) applied 4 sessions of 10 and $15 \mathrm{~Hz}$ rTMS with two-day intervals for two weeks in 2 groups of patients with $\mathrm{AD}$, including 6 patients in each group. Boston Diagnostic Aphasia Evaluation Test, Category Fluency Test and MMSE were used in the cognitive evaluation performed 2 weeks before and after the TMS application and 4 weeks after the last day of the application. Verbal agility score performed immediately after the application and non-verbal agility score after the test performed 4 weeks after TMS showed a statistically significant improvement compared to baseline. On the other hand, functional magnetic resonance imaging (fMRI) with cognitive tasks measuring motor and language functions was applied to 8 patients who were compatible with MRI before, immediately after and 4 weeks after rTMS application. According to fMRI results after magnetic stimulation, an increase in activity was observed in some patients, especially in Broca's area, but this increase was not statistically significant (19).

In the study by Rutherford et al. (31) in which the placebo effect was evaluated crossover, 10 patients with $\mathrm{AD}$ were divided into two groups as the sham-treatment group consisting of 4 patients and the treatment-sham group consisting of 6 patients. Twenty Hz rTMS application to the right-left DLPFC region was divided into two 4-week periods. In the first period, rTMS was applied to the treatment group, but not to the sham group. The cognitive status of the patients was measured with ADASCog and Montreal Cognitive Assessment (MoCA) tests at the beginning and end of the treatment, and with the MoCA test at the end of each week. The second 4-week period was planned one month later for the TMS effects to cease, and the groups were crossed and the same protocol was applied as the previous one. At the end of the study, the test scores of the treatment group were significantly higher than those of the sham group. In the second arm of the study, 10 sessions of rTMS were applied to 6 patients in 3 months with the same protocol. Extensive evaluations were made before and after the treatment, and the MoCA test was repeated every week for partial evaluation. According to the neuropsychological evaluation results of the patients in the treatment-sham group, cognitive improvement was observed after rTMS applications (31).

Fifty two patients with $\mathrm{AD}$, consisting of 26 sham controls and 26 patients receiving treatment, were included in the study in which the effects of rTMS combined with antipsychotic drugs on behavioral and psychological functions were examined. Wu et al. (32) applied $20 \mathrm{~Hz}$ stimulation to the left DLPFC region of patients using $1 \mathrm{mg}$ of risperidone for 20 sessions for 4 weeks.
The Behavioral Pathology in AD Rating Scale (BEHAVE-AD) and ADAS-Cog test scores were obtained before and 4 weeks after treatment. It was reported that both test results improved significantly in the rTMS group (32).

In an online TMS study, conducted by Rabey et al. (30), left IFG (Broca's area), left STG (Wernicke's area), right-left DLPFC and right-left PSAC regions were targeted. During a 6-week period, $10 \mathrm{~Hz}$ pulses were applied for 5 days a week, for a total of 30 sessions. Anatomical MR images were obtained from the patients for neuronavigational use. rTMS was applied to 3 determined localizations (the other 3 localizations in the following days), and during this time, the patient was given homework related to the stimulated region (syntax and grammar tasks for Broca's area, dictionary meaning and categorization tasks for Wernicke's area, action-object naming tasks and spatial memory tasks for rightleft DLPFC, and spatial attention tasks for right-left PSAC. High significance values were obtained in ADAS-Cog and MMSE scores in pre- and post-treatment comparisons. Seven months after the end of the treatment, 5 more patients were included in the study and a second treatment was performed with the same protocol. As a result, Rabey et al. (33) reported that ADAS-Cog scores improved compared to pre-treatment.

Lee et al. (22) divided the patients into two groups as the treatment group consisting of 18 patients 8 sham controls in the study in which they included 26 patients with AD. In this online study, in which rTMS application was performed simultaneously with cognitive tasks, stimulation was applied to Broca, Wernicke, right-left DLPFC and right-left PSAC regions. Syntax and grammar tasks for Broca's area, dictionary meaning and categorization tasks for Wernicke, action-object naming tasks and spatial memory tasks of shapes, colors, words for rightleft DLPFC, and spatial attention tasks of shapes and words were given for PSAC. Ten Hz frequency online rTMS protocol which was applied 5 days a week and 30 sessions for 6 weeks, Broca, Wernicke and right DLPFC areas were stimulated on the $1^{\text {st }}, 3^{\text {rd }}$ and $5^{\text {th }}$ days of the week, while the left DLPFC and the rightleft PSAC areas were stimulated on the $2^{\text {nd }}$ and $4^{\text {th }}$ days of the week, and it was aimed to stimulate only three brain regions in one session. Evaluation tests were performed 2 weeks before, at the end of treatment, and 6 weeks after treatment. ADAS-Cog scores in the treatment group differed significantly compared to the sham control. While no significant difference was observed in the first cognitive test comparisons, only the tests performed at 6 weeks after treatment in patients with mild $\mathrm{AD}$ showed significance. The GDS scores after treatment in the Sham group showed significant differences. In the CGIC applied immediately after the treatment, there was significant change in the treatment group compared to the sham control, but there was no significant difference between groups after 6 weeks (22).

Zhao et al. (34) divided 30 patients with mild and moderate $\mathrm{AD}$ into two groups as rTMS group consisting of 17 patients and sham control group consisting of 13 patients, and determined the magnetic field application area as parietal P3/ $\mathrm{P} 4$ and posterior temporal T5/T6 regions according to the 1020 electroencephalography system. Twenty $\mathrm{Hz}$ stimulations were 
applied 30 times for 6 weeks to the patients who underwent TMS application. Patients did 20-40 second off-line tasks after 10-minute sessions. MMSE, MoCA, and Auditory Verbal Learning Test (AVLT) were performed 2 weeks before, immediately after, and 6 weeks after treatment. It was reported that improvements in memory, language and cognitive functions were detected in especially patients with mild AD in the treatment group compared to all patients in the sham control group (34).

With the developments in neuromodulation and neuroimaging methods, it has become possible, in a way, to monitor how an intervention like TMS causes a functional change in the brain (35). Cognitive disorders that occur in patients with stroke with focal brain damage are generally not primarily related to the center of the injury (36). Disruption of functional neural network integrity can be associated with neurological or psychological diseases such as depression, obsessive compulsive disorder and schizophrenia. In this group of patients, in order to repair impaired neural association, non-invasive methods such as TMS or transcranial direct current stimulation ( $\mathrm{tDCS}$ ) can be aimed at stimulating neural plasticity and restoring lost cognitive abilities (35).

Brain is highly active even during resting-state phase, and therefore, active areas of brian produce signals depending to blood oxygen levels (BOLD). Analysis of the changes in these signals provides insight into brain connectivity. Therefore, during an fMRI in which resting state activity is measured, the functional activity of the brain can be manipulated with TMS application and it can be observed how TMS makes a change in the brain network (37). In addition to the use of TMS for therapeutic purposes, the effect of TMS on brain connectivity can be confirmed with fMRI so that data can be analyzed more accurately. By using MR and TMS devices together, resting state functional connectivity can be measured. This measurement can be obtained as a result of fMRI analyzes simultaneously with TMS stimulation (39). Apart from that, TMS can provide more precise data on how different localizations of the brain function by being used as a mapping tool (40).

Neuroimaging is the most appropriate option to determine the localization of non-invasive brain stimuli, to elucidate the mechanism, and to identify regions where cognitive functions were increased or decreased after TMS.

Currently, $\mathrm{AD}$ is the most common cause of dementia with no known cure. Cognitive decline increases as the disease progresses, and current therapeutic approaches are not effective in improving cognitive deficits or functional limitations. TMS appears to be a promising tool for this purpose, given its ability to modulate cortical excitability and neural network activity.

When we look at the studies in the literature, it is observed that beneficial results are obtained by stimulating the DLPFC area of the brain in patients with AD. In addition, it is observed that the treatment perspective is tried to be expanded by stimulating other different areas such as Broca, Wernicke, PSAC, posterior parietal region.
We can briefly list the factors affecting the success of treatment in TMS application as follows. Age and disease progression seem to be the most important factors in the potential to benefit from TMS. The response of younger patients with AD to TMS treatment is remarkably high. In addition, TMS applications, especially in individuals with MCI, have given more beneficial results than those with $\mathrm{AD}$. Because there is not much atrophy in patients with MCI, the cell stimulation mechanism can be activated more easily with TMS and thus the cognitive and behavioral losses can be compensated. However, since the progression continues faster and the atrophic process is at a more advanced level in $\mathrm{AD}$, beneficial results are not always obtained.

Another factor affecting the treatment process is the duration of TMS treatment. There is no consensus on the number of TMS sessions. However, studies show that as the number of sessions increases, the effectiveness of treatment also increases. In many centers, 10 sessions of TMS are applied for neurodegenerative and depressive patients. Statistically more significant results were determined in the treatment course of the patients in studies in which 20 sessions were applied or 54 sessions were applied at intervals.

Another issue regarding the efficacy of treatment is the application site. Studies have shown that bilateral DLPFC is used as the most stimulating region, especially in patients $\mathrm{AD}$. However, when this region is stimulated, although improvements are observed in behavioral and executive functions, sufficient progress is not achieved in memory functions. In the formation of this situation, it is possible that the memory uses many brain networks in a combined way, and in case of incomplete functioning of one of these networks, the memory also suffers a loss of function. Therefore, many researchers aim to improve memory and some other cognitive functions by stimulating different localizations and stimulating these localizations consecutively or in combination.

Online TMS paradigm is another factor that contributes to the effectiveness of treatment. Having the patient do a cognitive task while performing TMS actually makes it possible to perform two-way brain stimulation. For example, let's consider a patient with $\mathrm{AD}$ in whom DLPFC region is stimulated to correct executive dysfunction. While performing TMS, having this patient perform a cognitive task or test on executive functions will increase the power of effect. This can actually be thought of as a method to shorten the long-term progress of brain plasticity. Many studies available in the literature show that online TMS protocols provide more effective results.

\section{Conclusion}

As a result, although research in this area has increased significantly in recent years, there is still very little and the most effective stimulation parameters in terms of frequency, intensity, localization and stimulation duration are unknown. In addition, it is necessary to include functional and structural neuroimaging measures to reveal the neural mechanisms underlying the beneficial effects of TMS. Although the studies available in 
the literature have revealed the beneficial effects of TMS in the treatment of $\mathrm{AD}$, more in-depth and comprehensive studies are needed for TMS to be used as a routine treatment option in AD. In addition, our knowledge of how TMS works is very limited. Although we observe the effect it has on behavioral and cognitive functions of patients, we almost have no idea about what kind of interventions on which parameters cause this effect. The mechanism of action of TMS can be examined in more detail, for example, by evaluating neurotropic, anti-inflammatory and antioxidant mechanisms. This will pave the way for the TMS method to be used more widely as a treatment option and for many patients to benefit from this method.

Ethics Committee Approval: None requirred.

Informed Consent: None requirred.

Peer-review: Externally peer reviewed.

\section{Authorship Contributions}

Surgical and Medical Practices: H.A.V., M.Y.B., Concept: M.Y.B., Design: H.A.V., M.Y.B., Data Collection or Processing: H.A.V., Analysis or Interpretation: H.A.V., M.Y.B., Literature Search: H.A.V., M.Y.B., Writing: H.A.V., M.Y.B.

Conflict of Interest: No conflict of interest was declared by the authors.

Financial Disclosure: The authors declared that this study received no financial support.

\section{References}

1. Husain M, Schott JM, editors. Oxford Textbook of Cognitive Neurology and Dementia [Internet]. Oxford University Press; 2016 [cited 2018 Nov 13]. Available from: http://oxfordmedicine. $\mathrm{com} / \mathrm{view} / 10.1093 / \mathrm{med} / 9780199655946.001 .0001 / \mathrm{med}$ 9780199655946

2. Kobayashi M, Pascual-Leone A. Transcranial magnetic stimulation in neurology. Lancet Neurol 2003;2:145-56.

3. Cotelli M, Manenti R, Cappa SF, Zanetti O, Miniussi C. Transcranial magnetic stimulation improves naming in Alzheimer disease patients at different stages of cognitive decline. Eur J Neurol 2008;15:128692.

4. Wagner T, Valero-Cabre A, Pascual-Leone A. Noninvasive Human Brain Stimulation. Annu Rev Biomed Eng 2007;9:527-65.

5. Hallett M. Transcranial magnetic stimulation and the human brain. Nature 2000;406:147-50.

6. Wagner T, Rushmore J, Eden U, Valero-Cabre A. Biophysical foundations underlying TMS: setting the stage for an effective use of neurostimulation in the cognitive neurosciences. Cortex 2009;45:1025-34.

7. Deng ZD, Lisanby SH, Peterchev AV. Electric field depth-focality tradeoff in transcranial magnetic stimulation: simulation comparison of 50 coil designs. Brain Stimul 2013;6:1-13.

8. Wagner TA, Zahn M, Grodzinsky AJ, Pascual-Leone A. Threedimensional head model simulation of transcranial magnetic stimulation. IEEE Trans Biomed Eng 2004;51:1586-98.
9. Barker AT, Jalinous R, Freeston IL. Non-invasive magnetic stimulation of human motor cortex. Lancet. 1985;1(8437):1106-7.

10. Rotenberg A, Horvath JC, Pascual-Leone A. The Transcranial Magnetic Stimulation (TMS) Device and Foundational Techniques. In Humana Press, New York, NY; 2014 [cited 2018 Nov 13]. p. 3-13. Available from: http://link.springer.com/10.1007/978-1-49390879-0_1

11. Davis NJ, Gold E, Pascual-Leone A, Bracewell RM. Challenges of proper placebo control for non-invasive brain stimulation in clinical and experimental applications. Eur J Neurosci 2013;38:2373-7.

12. Fitzgerald PB, Fountain S, Daskalakis ZJ. A comprehensive review of the effects of rTMS on motor cortical excitability and inhibition. Clin Neurophysiol 2006;117:2584-96.

13. Najib U, Bashir S, Edwards D, Rotenberg A, Pascual-Leone A. Transcranial brain stimulation: clinical applications and future directions. Neurosurg Clin N Am 2011;22:233-51.

14. Fargo KN, Aisen P, Albert M, Au R, Corrada MM, DeKosky S, et al. 2014 Report on the Milestones for the US National Plan to Address Alzheimer's Disease. Alzheimer's Dement 2014;10:S430-52.

15. Freitas C, Mondragón-Llorca H, Pascual-Leone A. Noninvasive brain stimulation in Alzheimer's disease: systematic review and perspectives for the future. Exp Gerontol 2011;46:611-27.

16. Cantone M, Di Pino G, Capone F, Piombo M, Chiarello D, Cheeran $\mathrm{B}$, et al. The contribution of transcranial magnetic stimulation in the diagnosis and in the management of dementia. Clin Neurophysiol 2014;125:1509-32.

17. Innocenti I, Giovannelli F, Cincotta M, Feurra M, Polizzotto NR, Bianco G, et al. Event-related rTMS at encoding affects differently deep and shallow memory traces. Neuroimage 2010;53:325-30.

18. Manenti R, Cotelli M, Robertson IH, Miniussi C. Transcranial brain stimulation studies of episodic memory in young adults, elderly adults and individuals with memory dysfunction: a review. Brain Stimul 2012;5:103-9.

19. Devi G, Voss HU, Levine D, Abrassart D, Heier L, Halper J, et al. Open-label, short-term, repetitive transcranial magnetic stimulation in patients with Alzheimer's disease with functional imaging correlates and literature review. Am J Alzheimers Dis Other Demen 2014;29:248-55.

20. Liao X, Li G, Wang A, Liu T, Feng S, Guo Z, et al. Repetitive Transcranial Magnetic Stimulation as an Alternative Therapy for Cognitive Impairment in Alzheimer's Disease: A Meta-Analysis. J Alzheimers Dis 2015;48:463-72.

21. Sasaki N, Kakuda W, Abo M. Bilateral high- and low-frequency rTMS in acute stroke patients with hemiparesis: a comparative study with unilateral high-frequency rTMS. Brain Inj 2014;28:1682-6.

22. Lee J, Choi BH, Oh E, Sohn EH, Lee AY. Treatment of Alzheimer's Disease with Repetitive Transcranial Magnetic Stimulation Combined with Cognitive Training: A Prospective, Randomized, Double-Blind, Placebo-Controlled Study. J Clin Neurol 2016;12:57-64.

23. Turriziani P, Smirni D, Zappalà G, Mangano GR, Oliveri M, Cipolotti L. Enhancing memory performance with rTMS in healthy subjects and individuals with Mild Cognitive Impairment: the role of the right dorsolateral prefrontal cortex. Front Hum Neurosci 2012;6:62. 
24. Ahmed MA, Darwish ES, Khedr EM, El Serogy YM, Ali AM. Effects of low versus high frequencies of repetitive transcranial magnetic stimulation on cognitive function and cortical excitability in Alzheimer's dementia. J Neurol 2012;259:83-92.

25. Cotelli M, Manenti R, Cappa SF, Geroldi C, Zanetti O, Rossini PM, et al. Effect of transcranial magnetic stimulation on action naming in patients with Alzheimer disease. Arch Neurol 2006;63:1602-4.

26. Cotelli M, Calabria M, Manenti R, Rosini S, Zanetti O, Cappa SF, et al. Improved language performance in Alzheimer disease following brain stimulation. J Neurol Neurosurg Psychiatry 2011;82:794-7.

27. Bentwich J, Dobronevsky E, Aichenbaum S, Shorer R, Peretz R, Khaigrekht $M$, et al. Beneficial effect of repetitive transcranial magnetic stimulation combined with cognitive training for the treatment of Alzheimer's disease: a proof of concept study. J Neural Transm (Vienna) 2011;118:463-71.

28. Haffen E, Chopard G, Pretalli JB, Magnin E, Nicolier M, Monnin $\mathrm{J}$, et al. A case report of daily left prefrontal repetitive transcranial magnetic stimulation (rTMS) as an adjunctive treatment for Alzheimer disease. Brain Stimul 2012;5:264-6.

29. Rabey JM, Dobronevsky E, Aichenbaum S, Gonen O, Marton RG, Khaigrekht M. Repetitive transcranial magnetic stimulation combined with cognitive training is a safe and effective modality for the treatment of Alzheimer' s disease : a randomized, double-blind study. J Neural Transm 2013;120:813-9.

30. Eliasova I, Anderkova L, Marecek R, Rektorova I. Non-invasive brain stimulation of the right inferior frontal gyrus may improve attention in early Alzheimer's disease: A pilot study. J Neurol Sci 2014;346:318-22.

31. Rutherford G, Lithgow B, Moussavi Z. Short and Long-term Effects of rTMS Treatment on Alzheimer's Disease at Different Stages: A Pilot Study. J Exp Neurosci 2015;9:43-51.

32. Wu Y, Xu W, Liu X, Xu Q, Tang L, Wu S. Adjunctive treatment with high frequency repetitive transcranial magnetic stimulation for the behavioral and psychological symptoms of patients with Alzheimer's disease a randomized, double-blind, sham-controlled. Shanghai archives of psychiatry Oct 2015. p. 280-8.
33. Rabey JM, Dobronevsky E. Repetitive transcranial magnetic stimulation (rTMS) combined with cognitive training is a safe and effective modality for the treatment of Alzheimer's disease: clinical experience. J Neural Transm (Vienna) 2016;123:1449-55.

34. Zhao J, Li Z, Cong Y, Zhang J, Tan M, Zhang H, et al. Repetitive transcranial magnetic stimulation improves cognitive function of Alzheimer's disease patients. Oncotarget 2017;8:33864-71.

35. Sale M V., Mattingley JB, Zalesky A, Cocchi L. Imaging human brain networks to improve the clinical efficacy of non-invasive brain stimulation. Neurosci Biobehav Rev 2015;57:187-98.

36. Verdon V, Schwartz S, Lovblad K-O, Hauert C-A, Vuilleumier P. Neuroanatomy of hemispatial neglect and its functional components: a study using voxel-based lesion-symptom mapping. Brain 2010;133:880-94.

37. Caparelli EC, Backus W, Telang F, Wang GJ, Maloney T, Goldstein RZ, et al. Simultaneous TMS-fMRI of the Visual Cortex Reveals Functional Network, Even in Absence of Phosphene Sensation. Open Neuroimag J 2010;4:100-10.

38. Fox MD, Buckner RL, Liu H, Chakravarty MM, Lozano AM, PascualLeone A. Resting-state networks link invasive and noninvasive brain stimulation across diverse psychiatric and neurological diseases. Proc Natl Acad Sci 2018;111:E4367-75.

39. Fox MD, Halko MA, Eldaief MC, Pascual-Leone A. Measuring and manipulating brain connectivity with resting state functional connectivity magnetic resonance imaging (fcMRI) and transcranial magnetic stimulation (TMS). Neuroimage 2012;62:2232-43.

40. van de Ruit M, Perenboom MJ, Grey MJ. TMS brain mapping in less than two minutes. Brain Stimul 2015;8:231-9.

41. Liberati A, Altman DG, Tetzlaff J, Mulrow C, Gøtzsche PC, Ioannidis JP, et al. The PRISMA statement for reporting systematic reviews and meta-analyses of studies that evaluate healthcare interventions: explanation and elaboration. BMJ. 2009;339:b2700. 